$\begin{array}{ll}\text { Abstracta Iranica } & \begin{array}{l}\text { Abstracta Iranica } \\ \text { Revue bibliographique pour le domaine irano-aryen }\end{array} \\ & \text { Volume } \mathbf{2 4} \text { | } \mathbf{2 0 0 3} \\ \text { Comptes rendus des publications de } \mathbf{2 0 0 1}\end{array}$

\title{
Yode az Valizoda. Douchanbeh, Irfon, 2000, 128 p., biblio. [En se souvenant de Wâlîzâda]
}

\section{Stéphane A. Dudoignon}

\section{(2) OpenEdition}

Édition électronique

URL : http://journals.openedition.org/abstractairanica/34698

ISSN : 1961-960X

\section{Éditeur :}

CNRS (UMR 7528 Mondes iraniens et indiens), Éditions de l'IFRI

Édition imprimée

Date de publication : 15 mai 2003

ISSN : 0240-8910

\section{Référence électronique}

Stéphane A. Dudoignon, « Yode az Valizoda. Douchanbeh, Irfon, 2000, 128 p., biblio. [En se souvenant de Wâlîzâda] ", Abstracta Iranica [En ligne], Volume 24 | 2003, document 237, mis en ligne le 05 janvier 2010, consulté le 25 septembre 2020. URL : http://journals.openedition.org/abstractairanica/34698

Ce document a été généré automatiquement le 25 septembre 2020.

Tous droits réservés 


\title{
Yode az Valizoda. Douchanbeh, Irfon, 2000, 128 p., biblio. [En se souvenant de Wâlîzâda]
}

\author{
Stéphane A. Dudoignon
}

1 Ce recueil de souvenirs et hommages, en prose et en vers, de collègues, familiers et amis du hâfiz et chanteur populaire du Khawaling (sud du Tadjikistan) Sayyid 'Alî Wâlîzâda (1900-1971), offre sur son œuvre une suite de brèves évocations. En dépit - ou à cause - du caractère extrêmement conformiste de cette œuvre à la gloire de la collectivisation, nourrie de souvenirs doloristes de la période des émirs, ces évocations documentent utilement le milieu des lettres et des arts du Tadjikistan, et ses sociabilités bien particulières, pendant les deux premiers tiers $\mathrm{du} 20^{\mathrm{e}} \mathrm{s}$.

\section{INDEX}

Thèmes : 11.1.2. Littérature persane moderne

\section{AUTEURS}

STÉPHANE A. DUDOIGNON

Université Marc Bloch - Strasbourg 